\title{
Alternative Performance Measures and ESMA Guidelines: Improving Stakeholders' Communication
}

\author{
Francesca Magli ${ }^{1}$, Alberto Nobolo $^{1} \&$ Matteo Ogliari ${ }^{1}$ \\ ${ }^{1}$ Department of Business Administration, Finance, Management and Law in University of Milano - Bicocca, \\ Milan, Italy \\ Correspondence: Francesca Magli - Department of Business Administration, Finance, Management and Law in \\ University of Milano - Bicocca, Via Bicocca degli Arcimboldi, 8-Milan, Italy. E-mail: \\ francesca.magli@unimib.it
}

Received: June 18, 2017

Accepted: November 14, 2017

Online Published: November 20, 2017

doi:10.5539/ijbm.v12n12p15

URL: https://doi.org/10.5539/ijbm.v12n12p15

\begin{abstract}
In a world more interconnected and globalized, the Entities periodically communicate to stakeholders, and in general to market, their performances and results. The Entities use, in their financial communication, Alternative Performance Indicators (APM) that are not required by accounting principles. APM are increasingly used by Entities to help provide insights on performance. These indicators are a financial measure of historical or future financial performance, financial position, or cash flows, other than a financial measure defined or specified in the applicable financial reporting framework. This study aims to analyse the spread of APM, investigating the financial communications of Listed Italian Industrial Entities on FTSE-MIB index 40. As APM have become more widespread, their reporting has turned out to be an hot topic around the world for prepares, stakeholders, auditors and regulators. The European Securities and Markets Authority issued new guidelines that aim to improve the usefulness and transparency of Alternative Performance Measures. In the second part, the study aims to analyse how the Entities expects to apply these new guidelines and the impacts on financial communication.
\end{abstract}

Keywords: communication, agency theory, performance, financial indicator, economic indicator, alternative performance measure, non-gaap measure, guidelines

\section{Introduction}

The intensive development of capital and socio-cultural market factors affecting most countries led to the necessity for regulatory bodies to consider such factors with respect to the regulations of financial reporting.

Deficiencies in traditional financial reporting can be remedied by the accounting profession, because it is forced to issue very detailed standards to reduce these problems.

In 2005, Financial Accounting Standards Board (FASB) and International Accounting Standards Board (IASB) decided to reach agreement on a project of revising their conceptual frameworks, and redefine user groups, objectives of accounting reporting, and elements of financial statements. Further agreement was made as to rearrange qualitative characteristics and issue a new common conceptual framework (Rostami and Salehi, 2011).

Over the same period, the first recommendations on alternative performance measures (APM or non-GAAP measures) were made.

Since 2005, several updates on accounting principles and professional standards have been provided and, today, the regulatory bodies have realized the importance of updating APM regulations.

On June 30, 2015, the European Securities and Markets Authority (ESMA) issued new guidelines (NGL) regarding APM, substituting the advisory note issued in 2005 by the Committee of European Security Regulators (CESR). Entities thus had to adopt these guidelines from June 3, 2016 onwards, the national stock exchange regulators having to enforce them. In Italy, CONSOB (Commissione Nazionale per le Società e la Borsa-National Commission for Companies and the Stock Exchange) performed this duty, having already adopted the ESMA guidelines in December 2015.

Entities disclose their performance through various forms of financial communication, and stakeholders evaluate 
the performance using economic, financial, and patrimonial indicators, considering both actual and forecasted results. In an increasingly interconnected and globalized world, entities periodically communicate their results to their stakeholders and to the market in general. Financial statements show data and other information according to applicable accounting standards. However, in their financial communications, entities use APMs not required by accounting principles, but that show financial results synthetically.

As such, an APM is a financial measure of either historical or future financial performance, financial position, or cash flow, other than the items specified in the valid financial reporting framework. Italian entities can choose between national accounting principles (Organismo Italiano di Contabilità (OIC) - Italian Agency of Accounting), and international accounting principles (IFRS or IAS). OIC was formed in 2001 as a registered foundation, in response to the need perceived by public and private sector parties to establishing a national standard setter that would be appropriately representative and would voice national options on accounting matters. OIC founders include organizations largely representing the parties interested in accounting matters. On the other hand, the IASB is a not-for profit, public interest organization, overseen by a Monitoring Board of public authorities. The governance and process of IASB are designed to keep standard setting independent from special interests, while ensuring accountability to stakeholders worldwide.

Recently, entities have been using APMs increasingly, although they are not obliged to use these performance indicators and there are no specific rules regarding the calculation of APMs. Therefore, entities have the option of choosing whether and how to calculate them. The flexibility of APMs allows entities to communicate their performance, either actual or forecasted, in a synthetic and straightforward way, taking into consideration the specific features of their respective businesses.

\section{Information Asymmetry: Relation between Preparers and Users}

Financial reporting is important documentation that companies use to communicate financial information. The management is responsible for explaining qualitative and quantitative economic and financial information about their company to various classifications of users.

As such, accounting systems have a critical role in providing useful information to different and entitled users on capital markets (Alattar and Al-Khater, 2008).

Important obstacles that need to be overcome include resolving issues related to agency theory, to provide better and more transparent communication to users.

Agency theory explains the relationship between principals and agents in businesses. The problems that can exist in agency relationships are related to the different and varying interests of the principal and agent, especially when the principal is unable to verify what the agent is actually doing. Agency theory is also concerned with the different attitudes towards risk of both the principal and agent (Jensen and Meckling, 1976).

In addition to governance issues, the principal is represented by the shareholder and, in turn, the agent by the manager. To analyze issues related to financial reporting, we discuss the agent as a manager who prepares communications, and the principals as users of information (i.e., those who need information regarding the management's actions).
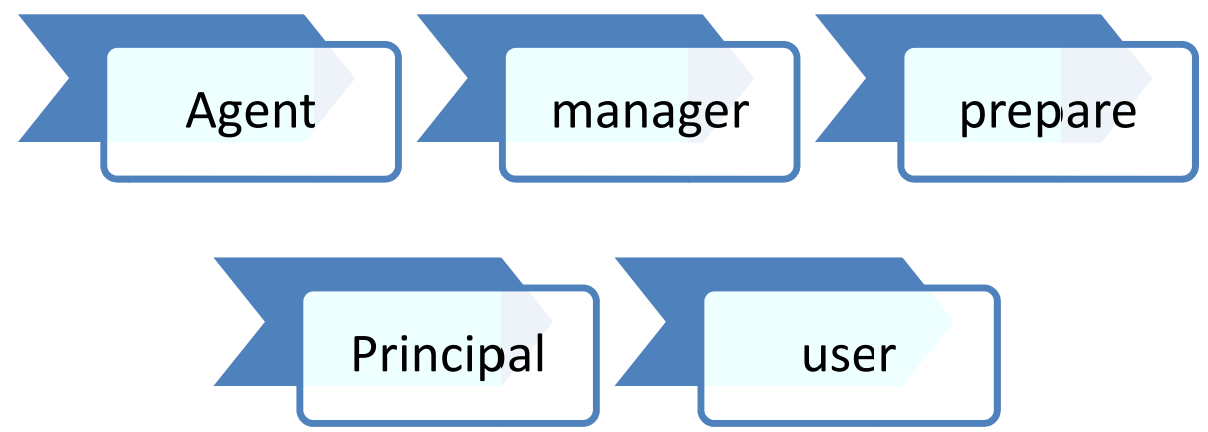

Figure 1. Agency theory logic in economic and financial communication

Information asymmetry in accounting and financial literature is divided into two types of analyses (Scott, 1997). 
The first is related to adverse selection, in which one party of the transaction does not have sufficient information. The party with less information is at disadvantage compared to the party with more information. The asymmetry causes lack of efficiency in financial information reporting.

The second type of analysis regards moral hazard, that is, the condition where one side performs activities the other groups are unaware of. Moral hazard occurs when one person takes more risks, because someone else bears the cost of those risks.

The first part of information asymmetry is known as hide information and the second as hide activities.

As such, due to market incompleteness and the presence of information asymmetry, the perceived value by users is different from the value for preparers.

These differences, according to Salehi and Rostami $(2011,2013)$, are due to:

- Information gaps, in which a gap exists between the adequate and desirable levels of disclosure and the current level; in this case, the perception of main performance data by the contributors does not transfer sufficiently;

- Quality gaps, which are differences between management performance, its objectives, and results, and what the society expects;

- Reporting gaps, which are the differences between business objectives and their respective achievements;

- Understanding gaps, which are differences between the different methods by which management and investors (users) evaluate data. To remedy gaps in understanding and approach, and solidify the value of information conveyed by financial reporting, one must use the most appropriate performance indicators to represent company value.

\section{Agency Theory and Alternative Performance Measures: Related Literature}

In terms of literature, we focus on agency theory, particularly on the relationship between performance and studies related to traditional and alternative performance indicators.

Disclosure policy emerges as a mechanism that can mitigate information asymmetry (the most important issue in agency theory) and lower firms' cost of external financing (Choi, 1973; Verrecchia, 1983). The optimal level of disclosure (Verrecchia, 1983, 2001) involves a trade-off between the benefit of a lower cost of external financing and the cost of revealing proprietary information (Francis et al., 2005:1127). Further, US empirical evidence shows that voluntary public disclosure reduces information asymmetry (Welker, 1995; Healy et al., 1999).

Another important analysis in relation to the disclosure level is the cost of equity capital (Botosan, 1997, 2006). According to Amihud and Mendelson (1986), by disclosing private information, firms can reduce the adverse selection component of their bid-ask spreads and cost of equity capital. According to Diamond and Verrecchia (1991), greater disclosure reduces the adverse price impact associated with large trades. This process leads to an increase in demand and, consequently, to an increase of the current price of firms' stock, which in turn reduces the cost of equity capital (Diamond \& Verrecchia, 1991, Amihud \& Mendelson, 1986).

Furthermore, a greater disclosure can reduce the cost of equity capital (Botosan, 2006) by diminishing the non-diversifiable estimation risk (Klein \& Bawa, 1976; Barry \& Brown, 1985; Handa \& Linn, 1993; Coles et al., 1995; Clarkson et al., 1996).

According to Armitage and Martson (2008), exists a relationship between the cost of equity and level of disclosure, but beyond a certain level of quality, it has limited effects on the cost of equity.

As previously mentioned, the problems that arise from agency theory refer to the separation of ownership and control being due to varying interests and the opposing incentive structures of shareholders and the manager. Therefore, this problem gives rise to an economic incentive alignment gap that must be filled to enable the manager to maximize shareholder wealth (Akindayomi, 2012, p. 42, Iyengar et al., 2005).

One of the most used tools to solve these problems is the executive stock option. The use of this or other incentive methods is predicated on the method by which performance is calculated, as performance measurement is a central problem in agency theory (Baker, 1992; Franco-Santos, 2009; Sloof \& Van Praag, 2007).

Traditional management accounting literature advocates the use of financial performance measures in evaluating managerial performance (Anthony, 1965; Merchant, 1998; El-shishini, 2001; Galeotti, 2002; Franco-Santos, 2009; Antonelli, 2010; Favotto et al., 2016).

The past four decades of accounting research have produced a substantial volume of work, showing that the 
market reacts positively to positive earnings news: indeed, earnings are value relevant (Kothari, 2001; Shon \& Zhou, 2011, p. 58).

Other researchers attribute several problems to the use of financial performance measures (Ridgway, 1956; Merchant, 1998). According to some scholars, financial performance measures are lagging indicators (Eccles and Pyburn, 1992, p. 41, Paulson Gjerde \& Hughes, 2007).

Because of these and other critiques, management accounting also supports the use of non-financial performance measures (Solomon, 1965, Parker, 1979, Kaplan, 1983, Ittner et al., 1997; Hoque \& James, 2000; Laitinen, 2002; Cerbioni et al., 2010; Zuriekat et al., 2011). (Note 1)

According to Ittner et al., the use of non-financial indicators is greater for firms following an innovation-oriented prospector strategy than those following a cost leader or defender strategy (1997).

In other studies, rather than analyzing financial versus nonfinancial indicators, indicators are analyzed following other characteristics, such as subjective versus objective, common versus unique, absolute versus relative, individual versus group, and local versus global (Ahn et al., 2010).

Ahn et al. (2010) also hypothesize that subjective measures are less discriminable than objective ones. In their hypothesis development, they assert that subjective performance measures often complement objective measures to mitigate the dysfunctional incentives caused by the latter, and are instrumental in reducing noise in performance measurement. Subject performance measures also mitigate the manipulation of objective measures (Bushman et al., 1996; Murphy \& Oyer, 2004). However, other scholars criticize that subjective performance measures arguing that are often inaccurate and unreliable (Feldman, 1981; Heneman, 1986; Golden, 1992;Boyne, 2006, p. 18).

Several studies exist on ambiguity, uncertainty, and appropriateness of accounting performance measures (Chapman, 1997; Hartmann 2000; Luft \& Shields, 2003). These works cite that management accounting literature has primarily adopted the contingency perspective, identifying uncertainty as the dominant determinant of the appropriateness of accounting performance measures (Hartmann, 2005, p. 242). The findings of Hartmann (2005) are that tolerance for ambiguity affects managers' opinions indirectly. In fact, the effect is moderated by the contingency variable, task uncertainty, and environmental uncertainty. Therefore, the relationship between the uncertainty and appropriateness of accounting performance measures is highly complex (Hartmann, 2005, p. 258).

An organization's inability to use total value as a basis for incentive contracts often leads to using a wide array of APMs, for example, the use of divisional accounting profits for the bonuses of division managers (Baker, 1992, p. 599).

The possible inappropriateness of financial indicators and the difficulty of using total enterprise value (e.g., for the calculation of executive pay) contribute to the need to identify other measures of performance. As such, companies use APMs to better represent their financial results and calculate executive pay.

Studies on APM increased after introducing their minimum regulation. Initially there were only Irish Auditing and Accounting Supervisory Authority (IAASA) publications (2012,2015), representing a survey on the use of APMs with key recommendations for practitioners, but other studies were subsequently published as ESMA, IFRS, and PricewaterhouseCoopers documents.

In the academic field, we find numerous studies after 2005 (Shoenberg, 2006; Marques, 2006, 2010; Heflin \& Hsu, 2008; Jennings \& Marques, 2011, Pham et al., 2011; Curtis et al., 2014; Baumker et al., 2014).

General studies that specifically analyze the value relevance of a comprehensive set of performance measures are the analysis by Habib (2010) on the relevance of APMs in Australian firms and Barton et al.'s (2009) study, which reports a similar analysis of companies around the world, with the largest number of observations from Japan and the United States.

The Barton et al.'s (2009) study compares the value relevance of a comprehensive set of performance measures (disclosed in financial statements) across 46 countries worldwide between 1996 and 2005. In their analysis, the value relevance of the performance measures varies substantially across line items in the income statement, as well as across countries.

Instead, Habib's (2010) analysis focuses on the Australian context and explores twice the sample size of Barton (2009), considering country-specific idiosyncrasies and small and medium-sized enterprises. The results reveal that earnings before interest, taxes, depreciation, and amortization (EBITDA) have the highest explanatory power, followed by total revenues. Total revenues have the highest explanatory power for small and medium 
companies, and operating income has the highest explanatory power for large firms. To strengthen the findings of such studies and in response to ESMA's recommendation, we used APM in a sample of Italian industrial entities listed on the FTSE-MIB index 40.

\section{New ESMA Guidelines}

On June 30, 2015, the ESMA issued new guidelines on APMs, substituting the advisory note issued in 2005 by CESR. The CESR issued its first document on APMs to define a high-level APM framework, but the document is not detailed and its application was not consistent.

These guidelines, pertaining to entities issuing listed stocks and bonds, require the disclosure of financial information, according to the Transparency Directive, and the submittal of an informative prospectus, according to the Prospectus Directive. Entities would have had to adopt the guidelines starting from June 3, 2016 onwards, and the national stock exchange regulators were to enforce them. In Italy, CONSOB performs this duty and, as previously mentioned, has already adopted ESMA guidelines in December 2015. The guidelines refer to all the APMs regularly used in financial communications and prospectuses, including management reports and press releases issued according to the Transparency Directive and communications about financial results according to the Market Abuse Regulation. However, these guidelines are not compulsory for financial statements (composed of balance sheet, income statement and notes).

The guidelines' aim is to improve the usefulness and transparency of APMs to stakeholders. To meet this requirement, guidelines require:

i) a clear indication of the APMs used and their components, together with the related assumptions (i.e., analysts should not use overoptimistic terms — e.g., certain profit — and should not define as non-recurring items revenues or costs that occurred in past periods and will occur again in the future-e.g., restructuring costs and impairment losses);

ii) a reconciliation between APMs and financial statement figures, including APM computation methods if they do not refer to financial statement data (e.g., in reference to future forecasts, entities should explain the application of accounting policies while calculating the APMs);

iii) not to display APMs with more prominence, emphasis, or authority over GAAP measures;

iv) APMs are also disclosed for comparative fiscal years;

v) coherent APMs are disclosed from one fiscal year to another. If the computation formula changes, entities should explain the reasons for the change and how this change will lead to more relevant and reliable information; moreover, entities should perform the restatement for the comparative year as well.

\section{Methodology}

Our study describes APMs' spread level. This research qualifies as applied research, because it aims at finding a solution for an immediate problem faced by the society or an industrial/business organization (Kothari, 2004:3).

Moreover, we use qualitative research because:

- We explore a new phenomenon;

- We need to generate conscience of this complex phenomenon, rooted in the perspective of the parties involved;

- We note the impossibility of separating the phenomenon investigated from the context in which it occurs.

Our research is descriptive one (Kothari, 2004:2) because it includes the results of benchmarking and surveys analysis.

To represent the quality of our study variables, we started with a benchmarking analysis. First, we determined the analysis population, that is, all main Italian listed companies, and then used appropriate means for data collection, that is, the analyses of financial reports performed during November and December 2015. During this period, we analyzed the financial reports of the Italian industrial entities listed on the FTSE-MIB index 40 as of December 2014.

We excluded financial institutions from the analysis because they are subject to specific rules, and the APMs of financial institutions are not comparable with the APMs of the industrial or service sectors.

Therefore, we analyzed the financial reporting available on the websites of 25 companies that are non-financial institutions. In Table 1, we report the list of companies analyzed for the purposes of our study. 
To perform the analyses, we prepared a checklist with specific questions. Then, we used the checklist for the analysis of each financial reporting from the companies on the list.

Specifically, we investigated the following topics:

- If entities adjust their financial statement figures in the calculation of APMs;

- If APMs have better economic and financial performance than the performance in financial statements;

- What are the most common adjustments that entities use to calculate APMs;

- How entities reconcile between the performances in financial statements and APMs;

- What are the most common APMs entities use in their financial communication.

After the analyses, we summarized the results and drawn our conclusions on the spread and use of APMs.

Table 1. Analysed industrial list companies-benchmarking

\section{Analysed Industrial List Companies - benchmarking}

$\begin{array}{lllll}1 & \text { A2A } & 10 & \text { FCA } & 19 \text { Stmicroelectronics } \\ 2 & \text { Ansaldo Sts } & 11 & \text { Finmeccanica } & 20 \text { Telecom Italia } \\ 3 & \text { Atlantia } & 12 & \text { Luxottica } & 21 \text { Tenaris } \\ 4 & \text { Buzzi Unicem } & 13 & \text { Mediaset } & 22 \text { Terna } \\ 5 & \text { Campari } & 14 & \text { Moncler } & 23 \text { Tod's } \\ 6 & \text { CNH Industrial } & 15 & \text { Pirelli } & 24 \text { World duty free } \\ 7 & \text { Enel } & 16 & \text { Saipem } & 25 \text { Yoox } \\ 8 & \text { Enel Green Power } & 17 & \text { Salvatore Ferragamo } & \\ 9 & \text { Eni } & 18 & \text { Snam } & \end{array}$

After the benchmarking analysis of APMs in the financial communication of listed companies, we also arranged a survey that was administered from January to March 2016.

To evaluate the effects of applying the new ESMA guidelines, we prepared the survey, in which we included questions about the main topics related to the NGL. Particular, the survey had the following sections:

- General information — questions on the entity, activities, and financial and economic performances;

- Use of APMs - questions on types of APMs, adjustments, and definitions;

- Expected impacts of NGL - areas affected by the changes, changes, and expected impacts;

- Efforts and planning of implementation of NGL-working group, type of resources, timing, and implementation costs.

Subsequently, we sent this survey on APMs and NGL to all Italian industrial listed companies (we sent out 300 questionnaires) and received 30 answers (that is, a $10 \%$ response rate). Specifically, the questionnaires were sent to the investor relations departments of the target companies. We considered all received answers.

The survey included a section on the current APMs utilized (whose results confirm the conclusions of the benchmarking on the 2014 financial statements mentioned above), a section about the changes that the issuers expect to face to comply with the new guidelines, and a final part about the efforts that the issuers expect to make to comply with the ESMA requirements. Particularly, we performed benchmarking analyses, followed by the survey. As reported above, the benchmarking identified the APMs in the 2014 financial communications of Italian companies, while the survey the possible impacts of NGL.

We highlight that some survey participants are not the same as those in our benchmarking analysis.

Table 2. List of participants-survey 


\section{List of participants - survey}

$\begin{array}{llll}\text { A2A } & 11 & \text { FCA } & \text { 21 Mutui on-line } \\ \text { Atlantia } & 12 & \text { Gefran } & \text { 22 Piquadro } \\ \text { Basic Net } & 13 & \text { Geox } & \text { 23 Poligrafici Editoriale } \\ \text { BE. Tse } & 14 & \text { Gruppo l'Espresso } & \text { 24 Retelit } \\ \text { Buzzi Unicem } & 15 & \text { Hera } & 25 \text { Safilo Group } \\ \text { Edison } & 16 & \text { Isagro } & \text { 26 Save - Aeroport di Venezia } \\ \text { Elica } & 17 & \text { Maire Tecnimont } & \text { 27 Servizi Italia } \\ \text { Enel } & 18 & \text { Mediaset } & \text { 28 Sogefi } \\ \text { ENI } & 19 & \text { Molmed } & \text { 29 Sol } \\ \text { ERG } & 20 & \text { Monrif } & 30 \text { Zignago }\end{array}$

\section{Benchmarking on Use of Alternative Performance Measures in the financial communications of Listed Companies: Analysis}

In the benchmarking analysis, we observe the number of entities using APMs, and the quality and transparency of those APMs. As shown in numerous research studies, high quality and transparent financial communication are essential for the proper functioning of the market. A framework for understanding the operations of accounting information in the economy isolates three channels through which financial communication can affect firms' investment, productivity, and value-creation. These channels involve the use of financial communications: 1) to identify promising investment opportunities; 2) to discipline managers to direct resources toward adequate projects and away from projects that primarily benefit managers rather than the owners of capital, and prevent embezzlement; and 3) to reduce information asymmetries among investors (Bushman and Smith, 2003).

It is a positive finding that the entities using APMs show their calculation methodologies and reconciliation between APMs and financial statements. However, these reconciliations are neither simple to identify nor to understand (e.g., positions of reconciliations are not clearly indicated and there is no guidance to understanding them). We noted that each company uses different reconciliation schemes, and the reconciliations are posted in different positions within the reports on operation or the explanatory notes to financial statements. Therefore, we think that APMs are useful tools, but entities should increase the quality and transparency of the data they disclose.

The main topics of our analysis can be summarized as follows:

- APMs and financial statements;

- the directions of adjustments;

- main adjustments to financial figures;

- $\quad$ most used APMs.

\subsection{APMs and Financial Statements}

Of the entities in the sample, $76 \%$ "adjust" their GAAP profits. These results prove that entities widely use APMs and prefer using APMs in their financial communications over financial statement figures. This is an important point to understand, and we will see in the next few analysis points why and how the entities adjust their figures.

\subsection{Direction of Adjustments}

The percentage of companies that make positive adjustments to their financial statement figures is $100 \%$.

In all analyzed cases, the adjustments each entity made to calculate APMs improved the entity's performance. As we did not identify negative adjustments to financial statement figures, we find it interesting that companies recorded only positive adjustments. Companies should identify the rules applied for the computation of APMs and apply those rules consistently over time. In this way, the adjustments should be positive or negative. In reality, although the companies define the rules for computation, they have the possibility to change the rules. On the other hand, auditors do not control the disclosed APMs. The results suggest that the analyzed companies use APMs to improve their performance results.

\subsection{Main Adjustments to Financial Figures}

The main adjustments entities perform on financial statement data are: 
i) Restructuring costs;

ii) Impairment test write-downs;

iii) Depreciation of tangibles and intangibles;

iv) Acquisition costs;

v) Adjustments to fair value of financial instruments;

vi) Exchange differences;

vii) Tax impacts.

In most cases, we noted that the "adjustments" were defined as "non-recurring items." In the CESR advisory note, there was no clear definition of such "non-recurring items," so it is up to the entities to define and disclose this definition. However, this definition was not identified in any of the analyzed cases.

As such, it is difficult to understand the real meaning of "non-recurring items." When we think about a "non-recurring item," we typically imagine something extraordinary in the entity's existence, probably a "one-shot item." However, when we come to the items the analyzed entities considered "non-recurring," we noted that the interpretations varied widely. Few items considered by the entities as "non-recurring" are actually non-recurring.

We assume that items that affected past periods and will affect future periods would be rarely considered as "non-recurring," infrequent, or unusual. In other words, a non-recurring item is a gain or loss found on a company's income statement that is not expected to occur regularly. Analysts seeking to measure the sustainable profitability of a company typically disregard non-recurring items, as these items are not expected to affect the company's future net income. Moreover, non-recurring items are not always easily identifiable, as they can appear under different sections on an income statement. Sometimes, non-recurring items are added to operating expenses, especially if closely connected to company operations. However, if the non-recurring item has a significant effect on the company's finances, it is listed net of tax on a separate line below the net income from continuing operations. Items related to new or discontinued operations, gains or losses due to accounting changes, and "extraordinary items" (items that are both unusual in nature and infrequent in occurrence) are listed this way.

According to Cameron and Stephens (1991), the separation of extraordinary items from other income statement items does not result in a separation of recurring from non-recurring items (Cameron and Stephens, 1991).

In our analyses, we identified that the outcome of usual accounting processes was also included in this category.

We propose some examples to better clarify the concept:

i) Every year, the entities have to perform the impairment test, so it is not extraordinary to record some write-downs;

ii) During the entity's life, it is normal to have restructurings and acquisitions, so we think that costs associated with these transactions are "recurring items;"

iii) During stock option plans, the entities have to record the associated costs, which are unclear because the entities considered these costs "non-recurring."

We believe that the adjustments performed and the definition of "non-recurring items" may mislead the users of financial communications. Our analysis shows that the items considered as "non-recurring" are those that affected past periods and will affect future periods (i.e., write downs, restructuring costs, stock option plan, etc.). Therefore, the most important part of adjustments that the companies use are not real "non-recurring items."

\subsection{Most Used APMs}

The most common APMs are

- $\quad$ EBITDA adjusted (43\%);

- $\quad$ EBIT adjusted (40\%);

- $\quad$ Result adjusted (10\%);

- $\quad$ Other (7\%).

The EBITDA and EBIT are profit achieved, and not considering extraordinary items. For the analyzed companies, we find different definitions of the "results" adjusted with the inclusion of extraordinary or non-recurring items. (Note 2) 
The analysis further indicates that the regulators are too optimistic. We noted some confusion about EBITDA, EBIT, and other APMs. The preparers define some APMs, but there is the possibility of manipulation because of the lack of clear definitions.

The question is whether financial statements and APMs are comparable.

It is important for stakeholders to evaluate the performance of entities, and an easy method to do this is to compare it with the competitors'. On the other hand, the managers of the entities want to show the best possible performance, so that they can achieve targets and obtain bonuses, increases, and new engagements.

We noted that many entities present in the primary financial statements some APMs, such as EBITDA and EBIT, then they adjust them in financial communications. We also noted that, when the entities present APMs in financial statements, it is a clear indication that data are not subject to audit. During our research, we noted that auditors do not verify APMs. We also understood that it is optional for auditors to check APMs because there is no set of accounting rules that apply in this case. Moreover, IFRSs do not require APMs, and that there are no definitions for them. Nonetheless, the auditor has the ability to check them.

Therefore, the question is "Who controls APMs?"

Our analyses show that entities apply different definitions of APMs (Note 3), which definitions either vary or do not exist. As such, auditors do not have the ability to check the application of APMs.

We believe that qualitative guidelines guarantee neither the comparability nor the transparency of APMs.

\subsection{Reconciliation between APMs and Financial Statements}

In most cases, it was not easy to identify the reconciliation between financial statement figures and APMs. Reconciliations are often too general and do not allow for the precise identification of the adjusted items.

\subsection{Reasons to Choose APMs}

In many cases, the entities did not report the reasons for their choice of APMs. Moreover, they did not explain why the management believed that APMs were important for explaining the entity's performance nor the reasons for their change from a fiscal year to the following.

We believe companies do not explain the reasons for use APMs, because they prefer the option to change them when the results of APMs do not reflect a better performance with respect to the figures in financial statements.

\section{Survey of New ESMA Guidelines}

In this survey, we obtained important information on the impacts entities expect from the application of NGL.

\subsection{Expected Changes}

The main expected changes by the entities are relative to:

- A clear indication of the used APMs and their components;

- A reconciliation between APMs and financial statement figures;

- Not displaying APMs with more prominence, emphasis, or authority than GAAP measures;

- Coherent APMs from one fiscal year to another.

7.2 Clear Indication of Used APMs and Their Components

Of the participants, 64\% expect a "low" impact of NGL and 36\% a "medium" impact, while none expect a "high" impact.

We consider the answers unusual because, as discussed above, our analysis showed that the use of APMs has certain relevant deficiencies. The NGL introduces many new requirements. Therefore, we would have expected different answers, where the impact would have been high because the company should significantly change financial communications to apply the NGL. Most likely, to date, the entity had not analyzed the NGL or significantly change the use of APMs.

The expected changes by entities in "non-recurring" items are specifically identified in financial statements, and in the adjustments for APMs computation these changes are depreciations and amortizations, devaluations, restructuring costs, acquisitions costs, exchange differences, and taxes.

\subsection{Reconciliation between APMs and Financial Statement Figures}

The entities do not expect significant changes because, in most cases (98\%), the entities that use APMs already reconcile these with financial statements figures. However, we noted no consistency where this reconciliation 
was reported; in some circumstances, they even reported it in more than one place (front half, face of the primary statement, notes, and other sections).

This is not a problem unless, as in the case of some entities, there exists a lack of signposting to where reconciliation could be found.

7.4 Not Displaying APMs with More Prominence, Emphasis, Or Authority Than GAAP Measures; APMs Indication also for Comparative Fiscal Years; And Coherent APMs from A Fiscal Year To Another

The entities do not expect significant impacts from this new requirement. Particularly, they declared they would analyze the prominence of using APMs, and already show comparative APMs.

During our analyses, we noted that entities do not show coherent APMs and do not explain why the APMs were relevant or, when they changed the APMs during the year, why they changed them.

We believe that the entities should significantly improve the quality of their APMs to make up for a lack of transparency and coherency of these APMs.

\subsection{Expected Efforts for Compliance}

Only two entities in the survey already arranged an internal work team to comply with the new ESMA guidelines. We noted that the two companies are prominent players in the energy and automotive sectors, and both have relevant activities in the United States.

\section{Conclusions}

We expect higher attention on APMs by regulators, and not only in Europe. Indeed, the new ESMA guidelines could change the way entities show their performance, in terms of better quality and transparency of their financial communications.

The survey shows an overall delay in the compliance with these guidelines. Since compliance is mandatory from July 3, 2016 onwards, entities will have to adopt the guidelines from the third quarter of 2016 at the latest. We would have actually suggested compliance from the first quarter of 2016 to avoid generating a change in financial communications during the fiscal year. We are unable to assess the effect of this change now. However, investors and financial analysts do use APMs to make their own choices and evaluate the company performance. Therefore, this change will undoubtedly have certain effects.

Along with financial statement approval deadlines, entities need to evaluate the potential impacts of the guidelines and be ready to submit more transparent, objective, and comparable APMs.

Our research shows many deficiencies in the use of APMs. Particularly, the benchmarking shows companies apply different definitions, there are no explanations in use of APMs, and in certain cases, the reconciliation between APMs and financial statements is unclear or difficult to understand.

We have some concerns regarding NGL. Particularly, we believe that the first problem is that NGL does not define APMs. Without an APM definition, entities have the option to manage APMs, and the individuals in-charge of governance or/and auditors have no real ability to control the correct application of APMs. As previously discussed, the entities do not have the opportunity to define some items as restructuring costs or impairment of assets as "non-recurring." However, considering that NGL does not define APMs, any entity can change them to "non-recurring" and include duplicate items in the APMs (i.e., restructuring costs or impairment of assets).

Moreover, entities do not expect relevant changes from the NGL. We believe that there are two possible scenarios: entities i) will delay the application of NGL or ii) will not want to make the change. We will thus analyze the application of NGL and we will study the impacts on financial communication.

During our research, we analyzed the use of APMs and how the NGL could change future financial communications. We also identified relevant deficiencies in the use of APMs and asymmetric information between preparers and users, but not only because the preparers use the APMs to pay bonuses, pay dividends, and in business combinations. Additionally, we learned that external auditors do not perform procedures on APMs.

As we have already summarized the main conclusions of our research, we ended with three specific suggestions (or themes) for future research on financial communications and APMs.

First, in terms of how the entities apply NGL and how the regulators perform enforcement, we call for more research on the transparency of the financial communications of entities and on the need to define clear rules. The new studies could exploit the effectiveness of the principal-based approached used by ESMA in the NGL. 
Second, we define the roles of those in-charge of governance, compensation committees, and independent directors in fixing and controlling the use of APMs in bonus compensations, dividend payments, and business combinations. We call for more research on corporate governance structures and the effectiveness of controls.

Third, we suggest more research is needed on the consistency between APMs and the IFRS data in the mid/long term. We hitherto have limited evidence that APMs show the real performance of entities. As such, the new research should analyze the link between APMs and IFRS figures.

\section{References}

Ahn, T. S., Hwang, I., \& Kim, M. (2010). The impact of performance measure discriminability on rate incentives. The Accounting Review, 85(2), 389-417. https://doi.org/10.2308/accr.2010.85.2.389

Akindayomi, A. (2012). The relationship between executive pay and alternative earning measure. Academy of Accounting and Financial Studies Journal, 16(4), 41-58.

Alattar J. M., \& Al-Khater, K. (2008). An empirical investigation of users' views on corporate annual reportis in Wuatar. International Journal Commerce and Management, 17(4), 312-325. https://doi.org/10.1108/10569210710844381

Amihud, Y., \& Mendelson, H. (1986). Asset princing and the bid-ask spread. Journal of Financial Economics, 17, 223-249. https://doi.org/10.1016/0304-405X(86)90065-6

Anthony, R. N. (1965). Planning and control systems: A framework for analysis. Boston: Harvard Graduate School of Business.

Antonelli, V. (2010). Modelli per la misurazione e la valutazione delle performance". In Rosella Ferraris Franceschi Sistemi di pianificazione e controllo. Torino, Giappichelli. 471-500.

Armitage S., \& Martson, C. (2008). Corporate disclosure, cost of capital: evidence from finance directors. The British Accounting Review, 40, 314-336. https://doi.org/10.1016/j.bar.2008.06.003

Baker, G. P. (1992). Incentive contracts and performance measurement. Journal of Political Economy, 100(3), 598-614. https://doi.org/10.1086/261831

Barry, C., \& Brown, S. (1985). Differential information and security market equilibrium. Journal of Financial and Quantitative Analysis (December), 407-422. https://doi.org/10.2307/2330758

Barton J., Hansen, B., \& Pownall, G. (2009). Which performance measure do investors value the most - and why? Retrieved from http://ssrn.com/abstract=1230562

Baumker, M., Biggs, P., McVay, S. E., \& Pierce, J. (2014). The Disclosure of Non-GAAP Earnings Following Regulation G: An Analysis of Transitory Gains. Accounting Horizons, 28(1), 77-92. https://doi.org/10.2308/acch-50645

Botosan, C. A. (1997). Disclosure Level and the cost of equity capital. The Accounting Review, 72(3), 323-349. https://doi.org/10.1080/00014788.2006.9730042

Botosan, C. A. (2006). Disclosure and the cost of capital: what do we know? International Accounting Policy Forum, 31-40.

Boyne, G. A. (2006). Public service performance: Perspectives on measurement and management. UK: Cambridge University Press. https://doi.org/10.1017/CBO9780511488511

Bushman, R., \& Smith, A. (2003). Transparency, Financial Accounting Information, and Corporate Governance. Retrieved from http://papers.ssrn.com/sol3/papers.cfm?abstract_id=795547

Bushman, R., Indjejikian, R., \& Smith, A. (1996). Individual performance evaluation. Journal of Accounting and Economics, 21, 161-194. https://doi.org/10.1016/0165-4101(95)00416-5

Cerbioni, F., Abdel_Maksoud, A., Ricceri, F., \& Velayutham, S. (2010). Employee morale, non-financial performance measures, deployment of innovative managerial practices and shop-floor involvement in Italian manufacturing firms. The British Accounting Review, 42(1), 36-55. https://doi.org/10.1016/j.bar.2010.01.002

Chapman, C. S. (1997). Reflections on a contingent view of accounting, Accounting. Organizations and Society, 22(2). https://doi.org/10.1016/S0361-3682(97)00001-9

Choi, F. (1973). Financial disclosure in relation to a firm's capital costs. Accounting and Business Research, 4, 282-292. https://doi.org/10.1080/00014788.1973.9729028 
Clarkson, P., Guedes, J., \& Thompson, R. (1996). On the diversification, observability and measurement of estimation risk. Journal of Financial and Quantitative Analysis (March), 69-84. https://doi.org/10.2307/2331387

Coles, J., \& Loewenstein, U. (1988), Equilibrium pricing and portfolio composition in the presence of uncertain parameters. Journal of Financial Economics, 279-303. https://doi.org/10.1016/0304-405X(88)90072-4

Coles, J., Loewenstein, U., \& Suay J. (1995). On equilibrium pricing under parameter uncertaintly. Journal of Financial and Quantitative Analysis, 347-364. https://doi.org/10.2307/2331345

Curtis, A. B., McVay, S. E., \& Whipple, B. C. (2014). The Disclosure of Non-GAAP Earnings Information in the Presence of Transitory Gains. The Accounting Review, 89(3), 933-958. https://doi.org/10.2308/accr-50683

Diamond, D., \& Verrecchia, R. E. (1991), Disclosure, Liquidity and the cost of equity capital. The Journal of Finance, 1325-1360. https://doi.org/10.1111/j.1540-6261.1991.tb04620.x

Eccles, R., \& Pyburn, P. J. (1992). Creating a comprehensive system to measure performance. Management accounting, 74(4), 41-44.

El-shishini, H. (2001), Integrating financial and non-financial performance measures: state of the art and research opportunities. Accounting Research Group Conference, Birmingham. https://doi.org/10.2139/ssrn.283651

Favotto, F., Bozzolan, S., \& Parbonetti, A. (2016). Economia aziendale. Modelli, misure, casi, McGrawHill.

Feldman, J. M. (1981), Beyond attribution theory: Cognitive processes in performance appraisal. The Journal of Applied Psychology, 66(1), 127-148. https://doi.org/10.1037/0021-9010.66.2.127

Francis, J. R., Khurana, I. K., \& Pereira, R. (2005), Disclosure Incentives and Effects on cost of capital around the world. The Accounting Review, 80(4), 1125-1162. https://doi.org/10.2308/accr.2005.80.4.1125

Franco-Santos, M. (2009). Performance measurement issues, incentive application and globalization. In Gomez_Meija L. and Werner S. (Eds.), Global compensation: fiundations and perspectives (pp. 41-56). Routledge.

Galeotti. (2002). Governo dell'azienda e indicatori di performance. Borghetto, Pisa.

Golden, B. R. (1992). SBU strategy and performance: the moderating effects of the corporate SBY relationship. Strategic management Journal, 13(2), 145-158. https://doi.org/10.1002/smj.4250130206

Habib A. (2010). Value relevance of alternative accounting performance measures: Australian Evidence. Accounting Research Journal, 23(2), 190-212. https://doi.org/10.1108/10309611011073269

Handa, P., \& Linn, S. (1993). Arbitrage pricing with estimation risk. Journal of Financial Economics (March), 81-100. https://doi.org/10.2307/2331152

Hartmann, F. (2005). The effects of tolerance for ambiguity and uncertainty of appropriateness of accounting performance measures. ABACUS, 41(3), 241-264. https://doi.org/10.1111/j.1467-6281.2005.00181.x

Hartmann, F. G. H. (2000). The appropriateness of RAPM: toward the further development of theory. Accounting, Organizations and Society, 25(4-5). https://doi.org/10.1016/S0361-3682(98)00036-1

Healy, P., Hutton, A., \& Pakepu, K. (1999). Stock performance and intermediation changes surrounding sustained increases in disclosure. Contemporary Accounting Research, 16, 485-520. https://doi.org/10.1111/j.1911-3846.1999.tb00592.x

Heflin, F. R., \& Hsu, C. (2008). The impact of the SEC's regulation of non-GAAP disclosures. Journal of Accounting and Economics, 46(2-3), 349-365. https://doi.org/10.1016/j.jacceco.2008.07.002

Heneman, R. L. (1986). The relationship between supervisory ratings and results oriented measures of performance: A meta analysis. Personnel Psychology, 39, 811-826. https://doi.org/10.1111/j.1744-6570.1986.tb00596.x

Hoque, Z., \& James, W. (2000). Linking Balanced Scorecard Measures to size and market factors: impact on organizational performance. Journal of Management Accounting Research, 12(1), 1-17. https://doi.org/10.2308/jmar.2000.12.1.1

Ittner, C. D., Larcker, D. F., \& Rajan, M. V. (1997). The choice of performance measures in annual bonus contracts. The Accounting Review, 72(2), 231-255.

Iyengar, R. J., Williams, H. J., \& Zampelli, E. M. (n.d.). Sensitivity of executive pay to accounting performance 
measures in all equity firms. Accounting and Finance, 45, 577-595.

Jennings, R., \& Marques, A. (2011). The Joint Effects of Corporate Governance and Regulation on the Disclosure of Manager-Adjusted Non-GAAP Earnings in the US. Journal of Business Finance \& Accounting, 38(3-4), 364-394. https://doi.org/10.1111/j.1468-5957.2011.02238.x

Jensen, M. C., \& Meckling, W. H. (1976), Theory of the firm: Managerial behavior, agency costs and ownership structure. Journal of Financial Economics, 3(4), 305-360. https://doi.org/10.1016/0304-405X(76)90026-X

Kaplan, R. S. (1983). Measuring manufacturing performance: A new challenge for managerial accounting research. Accounting Review, LVIII(4), 686-705. https://doi.org/10.1007/978-1-4899-7138-8_14

Klein, R. W., \& Bawa, V. S. (1976). The effect of estimation risk on optimal portfolio choice. Journal of Financial Economics, 3, 215-231. https://doi.org/10.1016/0304-405X(76)90004-0

Kothari, C. R. (2004). Research Methodology. Methods \& techniques. New age international limited Publishers, New Delhi.

Kothari, S. P. (2001). Capital markets research in accounting. Journal of Accounting and Economics, 31, 105-231. https://doi.org/10.1016/S0165-4101(01)00030-1

Laitinen, E. K. (2002). Financial Rating of European technology companies: an international comparison. Journal of Business Finance \& Accounting, 29(7-8), 871-901. https://doi.org/10.1111/1468-5957.00454

Luft, J., \& Shields, M. D. (2003). Mapping management accounting: Graphics and guidelines for theory-consistent empirical research. Accounting, Organizational and Society, 28(2-3).

Marques, A. (2006). SEC interventions and the frequency and usefulness of non-GAAP financial measures. Review of Accounting Studies, 11(4), 549-574. https://doi.org/10.1016/j.bar.2010.02.004

Marques, A. (2010). Disclosure strategies among S\&P 500 firms: Evidence on the disclosure of non-GAAP financial measures and financial statements in earnings press releases. The British accounting Review, 42(2), 119-131. https://doi.org/10.1016/S0361-3682(02)00026-0

Merchant, K. (1998). Modern management control system: Text and cases. Prentice Hall. https://doi.org/10.1007/s11142-006-9016-x

Murphy, K., \& Oyer, P. (2004). Discretion in executive incentive contracts. Working paper, University of Sothern California and Stanford University.

Parker, L. D. (1979). Divisional performance measurement: beyond an exclusive profit test. Accounting and Business Research, 36, 309-319.

Paulson Gjerde, K. A., \& Hughes, S. B. (2007). Tracking performance: When less is more. Management Accounting Quarterly, 9(1).

Pham, P. K., Suchard, J., \& Zein, J. (2011). Corporate governance and alternative performance measures: evidence from Australian firms. Australian Journal of Management, 36(3). https://doi.org/10.1080/00014788.1979.9729172

Ridgway, V. F. (1956). Dysfunctional consequences of performance measurements. Administrative Science Quarterly, 1, 240-247.

Rostami, V., \& Salehi, M. (2011). Necessity for reengineering the qualitative characteristics of financial reporting arrangement in the reduction of information asymmetry: An evidence of Iran. African Journal of Business Management, 5(8), 3274-3288. https://doi.org/10.1177/0312896211413035

Rostami, V., \& Salehi, M. (2013). Evaluation of Information Asymmetry in Financial reporting: Other approach, other result: New evidence from. Zagreb International Review of Economics \& Business, 16(2), 1-18. https://doi.org/10.2307/2390989

Scott, W. R. (1997). Financial accounting theory (3rd ed.). Prentice Hall.

Shoenberg, R. (2006). Measuring the Performance of Corporate Acquisitions: An Empirical Comparison of Alternative Metrics.

Shon, J., \& Zhou, P. (2011). Trading on Corporate earnings news: profiting from targeted. short-term options positions. FT Press

Sloof, R., \& Van Praag, C. M. (2007). Performance measurement, expectancy and agency theory: An experimental study. 
Solomons, D. (1965). Divisional performance: Measurement and control. Richard D. Irwin Inc. Homewood, Illinois.

Tutino, M. (2012). Performance e misurazione dei risultati nell'azienda. Franco Angeli, Milan

Verrecchia, R. E. (1983). Discretionary disclosure. Journal of Accounting and Economics, 5, 179-194. https://doi.org/10.1016/0165-4101(83)90011-3

Verrecchia, R.E. (2001). Essays on disclosure. Journal of Accounting and Economics, 32, 97-180. https://doi.org/10.1016/S0165-4101(01)00025-8

Welker, M. (1995). Disclosure policy, information asymmetry and liquidity in equity markets. Contemporary Accounting Research, 11, 801-827. https://doi.org/10.1111/j.1911-3846.1995.tb00467.x

Zuriekat, M., Salameh, R., \& Arawashdeh, S. (2011). Participation in Performance Measurement Systems and level of satisfaction. International Jorunal of Business and Social Science, 2(8), 159-169.

\section{Notes}

Note 1. For example, Solomon (1965) suggests measures for productivity market effectiveness, product leadership, personnel development, employees' attitudes. and public responsibility. Instead, Parker (1979) proposes measures for productivity, market share, social responsibility, product development, and employee turnover. Kaplan (1983) adds the elements of productivity, quality, inventory costs, product leadership, manufacturing flexibility, and delivery performance and Ittner et al. (1997) study 15 indicators (in addition to the aforementioned indicators, they add customer satisfaction, non-financial strategic objectives, innovation, employee satisfaction, workforce diversity, and leadership).

Note 2. We highlight that IFRSs do not define common performance indicators such as i) EBITDA, the formula is revenue - expenses (excluding interest, taxes, depreciation, and amortization); ii) EBIT (also called operating earnings, operating profit; the formula is: revenue - operating expenses; or iii) net financial position. The IFRS framework defines only operating results, while the APMs should be managed by national regulators. Before of NGL, the regulators in Europe defined only the net financial position. The entities would have used the same APMs, because they need to compare their performance against competitors.

Note 3. Some examples of different definitions of APMs (EBITDA):

- Company A-the Adjusted EBITDA is calculated without considering: i) fair value of financial derivatives instruments; ii) stock option plans; iii) restructuring costs;

- Company B-the Adjusted EBITDA is defined as net profit (loss) plus income tax expense, net financial income (expense), depreciation, amortization, "special costs," and the real/euro foreign exchange adjustments.

In this example, we show that Company A did not define the rules to calculate EBITDA, but only defined the adjustments. We note that all adjustments are recurring items. The Company B defined the rules to calculate EBITDA starting from net results and it did not consider in EBITDA adjusted "special costs" and the real/euro foreign exchange adjustments. First, Company B did not define "special costs" and, second, all adjustments are recurring items. The examples of Companies A and B shows that the comparability of companies is not guaranteed, and stakeholders do not have the possibility to compare performances.

\section{Copyrights}

Copyright for this article is retained by the author(s), with first publication rights granted to the journal.

This is an open-access article distributed under the terms and conditions of the Creative Commons Attribution license (http://creativecommons.org/licenses/by/4.0/). 